\title{
A reassessment of the vocalizations of three species of Ololygon (Anura: Hylidae) from southeastern Brazil
}

\author{
Davi Lee Bang ${ }^{1,2}$ and Ariovaldo Antonio Giaretta ${ }^{1}$ \\ ${ }^{1}$ Laboratório de Taxonomia, Ecologia Comportamental e Sistemática de Anuros Neotropicais, Universidade Federal de \\ Uberlândia, Faculdade de Ciências Integradas do Pontal, Rua 20, 1600, Bairro Tupã, 38304-402, Ituiutaba, MG, Brazil. \\ ${ }^{2}$ Programa de Pós-Graduação em Biologia Comparada, Universidade de São Paulo, Departamento de Biologia/FFCLRP, \\ Avenida dos Bandeirantes, 3900, 14040-901, Ribeirão Preto, SP, Brazil. E-mail: davileebang@yahoo.com.br.
}

\begin{abstract}
A reassessment of the vocalizations of three species of Ololygon (Anura: Hylidae) from southeastern Brazil. The vocalizations of Ololygon hiemalis, O. ranki, and $O$. canastrensis are redescribed to provide further details on their complex vocal repertoires. The acoustic diagnosis of $O$. hiemalis is updated in relation to congeners, especially with respect to the morphologically similar $O$. ranki, for which we also evaluate the morphological diagnosis of both species. Three distinct types of notes are recognized in the vocalization of the three species (short squawk-like, long squawk-like and click-like), which are emitted in distinct acoustic organizations. The main organization of the three species is herein referred as the call Type "A", each of which has a multi-note structure composed of a series of short squawk-like notes with note-by-note increase in amplitude along call duration. The call Type A of $O$. hiemalis was not described in the species original description. That of topotypes of $O$. ranki structurally resembles the call described in the original species description. Likewise, The call Type A of $O$. canastrensis matches that described in the original species description. Although $O$. hiemalis and $O$. ranki are phenotypically indistinguishable, there are quantitative differences in some call traits. Many species of Ololygon have complex vocalizations consisting of, at least, two types of notes, which can be emitted in different combinations. Despite the complexity of acoustic emissions, the call Type A of many species seems to be phylogenetically conserved. Because calls sometimes are only briefly described, we emphasize the need for, and importance of, comprehensive characterizations of anuran vocalizations to support future acoustic comparisons.
\end{abstract}

Keywords: acoustic diagnosis, advertisement call, complex vocal repertoire, Ololygon canastrensis, Ololygon hiemalis, Ololygon ranki, taxonomy. 


\begin{abstract}
Resumo
Uma reavaliação das vocalizações de três espécies de Ololygon (Anura: Hylidae) do sudeste do Brasil. As vocalizações de Ololygon hiemalis, $O$. ranki e $O$. canastrensis são redescritas para fornecer detalhes adicionais em seus complexos repertórios vocais. A diagnose acústica de $O$. hiemalis é atualizada em relação ao seus congêneres, especialmente em relação ao seu morfologicamente semelhante $O$. ranki, o qual nós também avaliamos suas diagnoses morfológicas. Três tipos distintos de notas são reconhecidos na vocalização das três espécies (grunhido curto, grunhido longo e estalos), os quais são emitidos em diferentes organizações acústicas. A principal organização acústica das três espécies é aqui referida como o canto Tipo "A", cada um dos quais possui uma estrutura multi-nota composta de uma série de grunhidos curtos com aumento nota por nota em amplitude ao longo da duração do canto. O canto Tipo A de $O$. hiemalis não foi descrito na descrição original da espécie. O canto Tipo A de topótipos de $O$. ranki assemelha-se estruturalmente com os cantos descritos na descrição original da espécie. Da mesma forma, o canto Tipo A de $O$. canastrensis é equivalente àqueles cantos descritos na descrição original da espécie. Embora Ololygon hiemalis e $O$. ranki sejam fenotipicamente indistinguíveis, existem diferenças quantitativas em algumas características dos cantos. Várias espécies de Ololygon possuem vocalizações complexas que consistem de, pelo menos, dois tipos de notas que podem ser emitidos em diferentes combinações. Apesar da complexidade de emissões acústicas, o canto Tipo A de várias espécies parece ser filogeneticamente conservado. Visto que cantos de algumas espécies são apenas brevemente descritas, nós enfatizamos a necessidade de, e importância de, caracterizações compreensivas das vocalizações de anuros para suportar comparações acústicas futuras.
\end{abstract}

Palavras-chave: canto de anúncio, diagnose acústica, Ololygon canastrensis, Ololygon hiemalis, Ololygon ranki, repertório vocal complexo, taxonomia.

\section{Introduction}

Anurans can broadcast distinct acoustic signals depending on the social context (Bastos and Haddad 2002, Bastos et al. 2011, Brunetti et al. 2015, Toledo et al. 2015), such as advertisement, aggressive, and territorial calls (Wells 2007). Advertisement calls are widely used for delimiting species units, supplementing species diagnoses (Padial et al. 2008), and revealing diversity in groups with conservative morphology (Carvalho and Giaretta 2013). Furthermore, advertisement calls have been used to address questions at the interspecific level to elucidate macroevolutionary patterns (Cocroft and Ryan 1995, Erdtmann and Amézquita 2009, Forti et al. 2017), and at the intraspecific level to detect patterns of variability in acoustic signals (Faria et al. 2013, Carvalho et al. 2015).

A recent phylogenetic study based on molecular data (Duellman et al. 2016) proposed the resurrection of the genus Ololygon Fitzinger,
1843 to accommodate all species of the former Scinax catharinae Clade (Faivovich 2002, Faivovich et al. 2005). Ololygon currently comprises more than 40 species distributed mostly through the Coastal Atlantic Forest of eastern Brazil (Duellman et al. 2016). Most species are forest dwellers, although few are known to inhabit gallery forests in the Cerrado Domain of Central Brazil (Cardoso and Haddad 1982, Pombal and Bastos 1996, Pombal et al. 2010, Lourenço et al. 2013).

Some taxonomic issues still remain in Ololygon because of the morphological similarities of its species. The vocalizations of several species of Ololygon are described, although some of them are only briefly or in some cases, only note types other than advertisement ones are reported. Herein, we redescribe the vocalizations of Ololygon hiemalis (Haddad and Pombal, 1987), O. ranki (Andrade and Cardoso, 1987) and O. canastrensis (Cardoso and Haddad, 1982) on the basis of new data, 
with the aim of providing further details of their complex vocal repertoires and contribute to the understanding of their taxonomy. Also, considering the re-description of the vocalization of $O$. hiemalis, we update the acoustic comparisons of it with respect to congeners and evaluate the species diagnosis in relation to the morphologically similar $O$. ranki.

\section{Materials and Methods}

Fieldwork was conducted at the following localities in southeastern Brazil: São Paulo state: Campinas Municipality: (1) Serra das Cabras, Joaquim Egídio District [2254'44.92" S, $46^{\circ} 50^{\prime} 03.32^{\prime \prime} \mathrm{W} ; 885 \mathrm{~m}$ a.s.1., $15 \mathrm{~km}$ from the type locality of Ololygon hiemalis (Fazenda Santana in Sousas)]; Minas Gerais state: (2) Poços de Caldas Municipality: $\left(21^{\circ} 46^{\prime} 31.13^{\prime \prime} \mathrm{S}\right.$, 4637'23.2" W; $1257 \mathrm{~m}$ a.s.l.; $17 \mathrm{~km}$ from the type locality of Ololygon ranki); (3) São Roque de Minas Municipality: Parque Nacional da Serra da Canastra $\left(20^{\circ} 14^{\prime} 36.60^{\prime \prime} \mathrm{S}, 46^{\circ} 26^{\prime} 48^{\prime \prime} \mathrm{W}\right.$; $1362 \mathrm{~m}$ a.s.l.; type locality of Ololygon canastrensis); (4) Perdizes Municipality: Estação de Pesquisa e Desenvolvimento Ambiental Galheiro (EPDA-Galheiro) (19¹2'27" S, 4708'31.23" W; $838 \mathrm{~m}$ a.s.1.; $130 \mathrm{~km}$ northwest from the type locality of $O$. canastrensis). Specimens examined are housed in the following Brazilian collections: Collection of Anurans from Universidade Federal de Uberlândia (AAG-UFU), Uberlândia, Minas Gerais; Collection of Amphibians Célio F. B. Haddad (CFBH), Universidade Estadual Paulista Júlio de Mesquita Filho, Rio Claro, São Paulo; and Museum of Zoology of Universidade Estadual de Campinas (ZUEC), Campinas, São Paulo. Species identifications were based on original species descriptions (Cardoso and Haddad 1982, Andrade and Cardoso 1987, Haddad and Pombal 1987) and on type-series specimens. Specimens examined are listed in Appendix I.

Adult male frogs were measured following the conventions of Watters et al. (2016): SVL (snout-vent length); HW (head width); HL (head length); ED (eye diameter); IOD (interorbital distance); IND (internarial distance); EN (eyenostril distance); TD (tympanum diameter); SL (snout length); TL (tibia length); THL (thigh length); FL (foot length); HAL (hand length); UEW (upper eyelid width); Fin4DW (finger IV disk width); and Toe4DW (toe IV disk width). Measurements were taken with an ocular micrometer under a stereomicroscope, except for SVL, TL, THL, and FL, which were taken with a Mitutoyo caliper to the nearest $0.1 \mathrm{~mm}$.

Sound files (Appendix II) are housed in the AAG-UFU sound collection and in Fonoteca Neotropical Jacques Vielliard (FNJV), Universidade Estadual de Campinas, Campinas, São Paulo. Vocalizations were recorded in the field using a Marantz PMD 671 and a M-audio Microtrack II recorders set at $48 \mathrm{kHz}$ or 44.1 $\mathrm{kHz}$ sampling rates and 16-bit resolution (mono wav format) coupled to Sennheiser K6/ME67 or K6/ME66 microphones. Calls were analyzed using Raven Pro 1.5 (Bioacoustic Research Program 2012) with the following settings: window type $=$ Hann, window size $=256$ samples; $3 \mathrm{~dB}$ filter bandwidth $=270 \mathrm{~Hz}$ or $248 \mathrm{~Hz}$; overlap (locked $)=90 \%$; hop size $=0.542 \mathrm{~ms}$ or 0.590 ms; DFT size = 1024 samples; spectral resolution $=46.9 \mathrm{~Hz}$ or $43.1 \mathrm{~Hz}$. Brightness and contrast were set at $60 \%$ and $75 \%$, respectively. All other settings followed the software default values. Calls were filtered up to $200 \mathrm{~Hz}$ prior to analysis to reduce background (mostly wind) noise; calls of $O$. ranki from Poços de Caldas were filtered up to $800 \mathrm{~Hz}$ owing to significant background rain noise. Temporal features were measured manually in the oscillogram. Dominant frequency was obtained with the Peak Frequency function; call rise and note rise time were measured through Peak Time function. Acoustic terminology and definitions are listed in Table 1. Sound figures were made in the Seewave package version 1.7.6 (Sueur et al. 2008) in the $\mathrm{R}$ platform version 3.2.3 ( $\mathrm{R}$ Development Core Team 2015), using the following settings: window $=$ Hanning, overlap $=85 \%$ and FFT $=256$. 
Table 1. Acoustic terminology and definitions employed in the present work.

\begin{tabular}{|c|c|}
\hline Call traits & Definition \\
\hline Call Type A duration & $\begin{array}{l}\text { Time from beginning to end of one call; Call Type A for the three species studied } \\
\text { herein = group of short squawk-like notes. }\end{array}$ \\
\hline Call rise time & Point of maximum amplitude of a call Type A divided by its duration (x 100). \\
\hline Number of notes & Total number of short squawk-like notes emitted in a single call. \\
\hline Note duration & Time from beginning to end of one note. \\
\hline Note period & $\begin{array}{l}\text { Time comprising the beginning of one note to the beginning of the next note. Measured } \\
\text { from the first, middle and last portion within a call Type A. }\end{array}$ \\
\hline Note rise time & Point of maximum amplitude of a short squawk-like note divided by its duration (x100). \\
\hline Note rate & $\begin{array}{l}\text { Total number of notes per call }-1 / \text { duration from the beginning of the first note to the } \\
\text { beginning of the last note within a call. Given as notes/s. }\end{array}$ \\
\hline Internote interval & Time from the end of a note to the beginning of the next note. \\
\hline Number of pulses & Total number of pulses per note. \\
\hline Pulse duration & Time from beginning to end of a single pulse. \\
\hline Pulse rate & $\begin{array}{c}\text { Total number of pulses per note }-1 / \text { duration from the beginning of the first pulse to the } \\
\text { beginning of the last pulse within a note. Given as pulses/s. }\end{array}$ \\
\hline Dominant frequency & Frequency with greatest energy, determined from the first, middle and last notes. \\
\hline
\end{tabular}

We had access to the analogue recordings (provided by the FNJV) analyzed by Andrade and Cardoso (1987) in the original description of Ololygon ranki. The low sound input and age of these recordings might hamper an accurate analysis and therefore, we used them only to figure calls for between-species comparisons.

Recently, an acoustic revision of Ololygon (as Scinax catharinae Clade; Hepp et al. 2017) classified notes as: (1) short squawk-like notes (Figure 1A, D, G); (2) long squawk-like notes (Figure 1B, E, H); and (3) click-like notes (Figure 1C, F, I). Further, the authors classified calls based on the note organization, and the main one that is used in interspecific comparisons was classified as call "Type A" (i.e., assumed to be the advertisement call; Bastos and Haddad 2002, Bastos et al. 2011, Hepp et al. 2017). We follow these authors in an attempt to standardize the acoustic terminology for future comparisons. In contrast, we do not use the classification of other call types because the emission of notes that compose these other call types is too variable to delimit them consistently. We realize that further behavioral and experimental investigations (Bastos and Haddad 2002, Bastos et al. 2011), along with an understanding of the mechanical processes of call production (Martin 1972) are needed to clear understand the patterns of acoustic emission on this genus and to establish homologies between acoustic units.

We tested the interspecific discrimination in morphometric and acoustic data between Ololygon hiemalis and $O$. ranki with the following functions: (1) randomForest (RF) (randomForest v. 4.6-12 package; Liaw and 
A
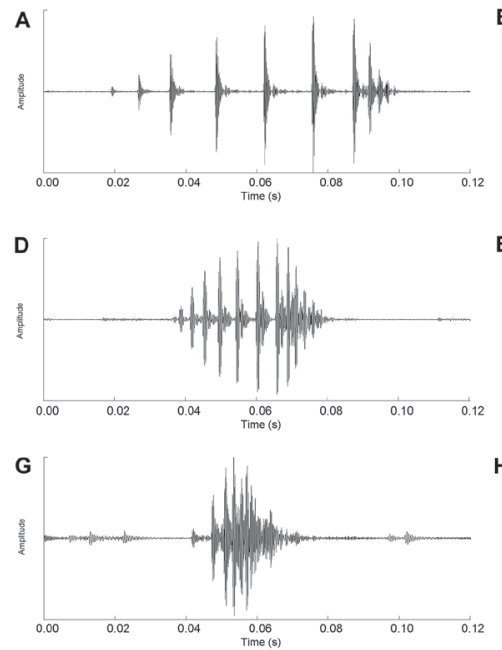
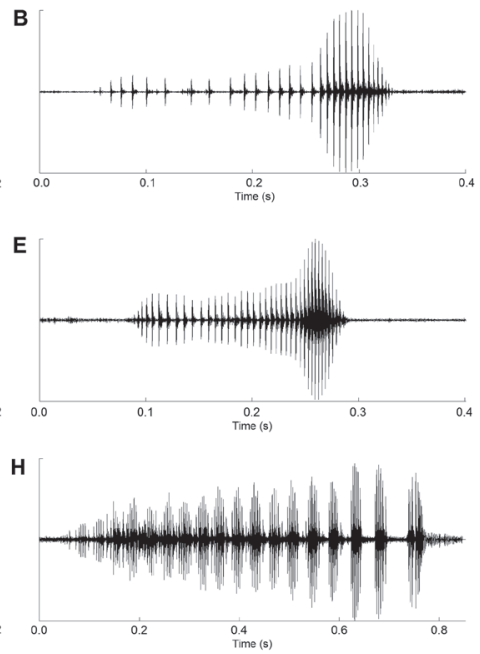

C
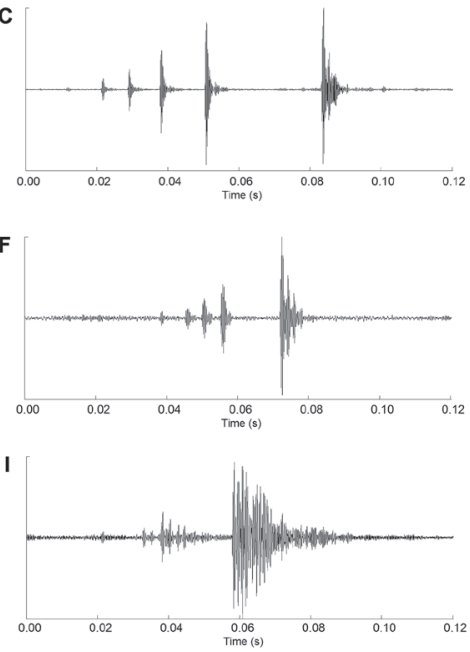

Figure 1. Oscillograms depicting the acoustic signals of the three species. Ololygon hiemalis: (A) short squawk-like note; (B) long squawk-like note; (C) click-like note (sound file=Ololygon_hiemalCampinasSP12dAAGm671). O ranki: (D) short squawk-like note (sound file = Ololygon_rankiPocosCaldasMG13aAAGm); (E) long squawk-like note (sound file = Ololygon_rankiPocosCaldasMG14aAAGm); $(\mathbf{F})$ click-like note $($ sound file = Ololygon_rankiPocosCaldasMG7aAAGm). O. canastrensis: $(\mathbf{G})$ short squawk-like note (sound file = Ololygon_canastrPerdizesMG4bAAGm671); (H) long squawk-like note (sound file = Ololygon_ canastrPerdizesMG6aTRC_AAGmt); (I) click-like note (sound file = Ololygon_canastrCanastraMG1bLBM_ AAGmt). See further details on sound files in Appendix II.

Wiener 2002), and (2) DAPC (Discriminant Analysis on Principal Components, adegenet v. 2.0.1 package; Jombart 2008, Jombart et al. 2010), both in the R platform. The RF algorithm constructs many (e.g., 500) classification trees using bootstrap samples of the data; each split uses the best predictors among those randomly chosen at each node, and then generates classifiers and aggregates results by voting to classes (Liaw and Wiener 2002). The RF results include an estimate of distances among the objects, and such distances can be subject to a Multidimensional Scaling Analysis and displayed graphically with the rfPermute package (Archer 2014). The DAPC performs the analyses on the Principal Component scores (Jombart 2008, Jombart et al. 2010). The application of a DA on a few axes (retaining approximately $95 \%$ of the variance) of a Principal Component Analysis, as performed by DAPC, improves the imbalance between objects and traits (Jombart et al. 2010). DPAC analysis was conducted in an exploratory context to assess the congruence between it and RF discrimination. We tested the traits indicated as important for discrimination by both functions (RF and DAPC) for statistical significance for interspecific differences with the Exact MannWhitney-Wilcoxon Rank Sum Test (function wilcox test) using the package coin v. 1.1-3 (Hothorn et al. 2008) in R. Values of $p<0.05$ were considered to be significant.

\section{Results}

\section{Morphology and Species Identification}

Ololygon hiemalis (Figure 2A): (1) males small- to moderate-sized $(\mathrm{SVL}=23.3-30.7 \mathrm{~mm}$, 
mean $=26.7, \mathrm{SD}=2.0 ; N=25$ males $)$; summary of morphometric features in Table 2; (2) snout subelliptical, subovoid, or rounded in dorsal view; (3) rounded in lateral profile; (4) ventral inguinal folding present; (5) dorsum with scattered granules; (6) a dark brown, triangular blotch in interorbital region delimited by (7) a pair of cream stripes extending from posterior margin of eye to inguinal region, forming an almost inverted parenthesis-like shape; irregular small blotches within the stripes in some specimens.

Ololygon ranki (Figure 2B): (1) males smallto moderate-sized $(\mathrm{SVL}=17.5-27.8 \mathrm{~mm}$, mean $=23.9, \mathrm{SD}=2.9 ; N=48$ males); summary of morphometric features in Table 2; (2) snout subelliptical, subovoid or rounded in dorsal view; (3) rounded in lateral profile; (4) ventral inguinal folding present; (5) dorsum smooth with scattered granules; (6) a dark brown, triangular blotch in interorbital region delimited by (7) a pair of cream stripes extending from posterior margin of eye to inguinal region, forming an almost inverted parenthesis-like shape; irregular small blotches within the stripes in some specimens.

Specimens from EPDA-Galheiro (Figure 2C) match the original diagnosis of Ololygon canastrensis (Cardoso and Haddad 1982), based on the following set of characters: (1) males small- to moderate-sized ( $\mathrm{SVL}=25.0-29.8 \mathrm{~mm}$, mean $=27.3, \mathrm{SD}=1.9 ; N=7$ males); (2) snout subelliptical or subovoid in dorsal view; (3) rounded in lateral profile; (4) dorsal skin granulose; (5) a dark brown, triangular or trapezoidal blotch in interorbital region delimited by (6) two dorsolateral elongated dark brown blotches extending from posterior margin of eye to midbody and a chevron-shaped blotch on the sacral region.

\section{Vocalization of the Three Species}

General traits.-The vocalizations of all three species of Ololygon consist of three types of signals herein referred to as (1) short squawklike (Figure 1A, D, G), (2) long squawk-like (Figure 1B, E, H), and (3) click-like notes (Figure 1C, F, I), which were emitted in different
A

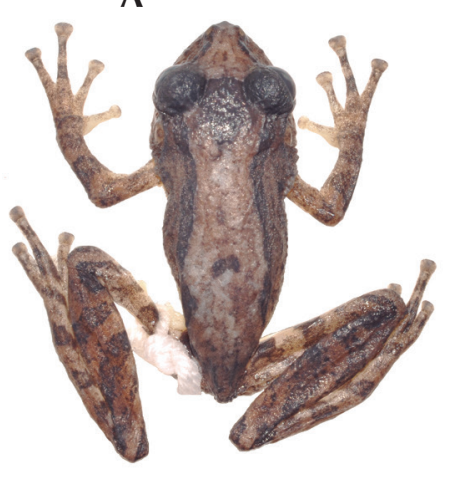

B

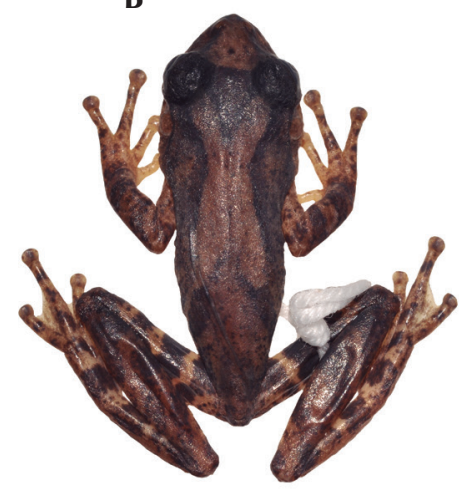

C

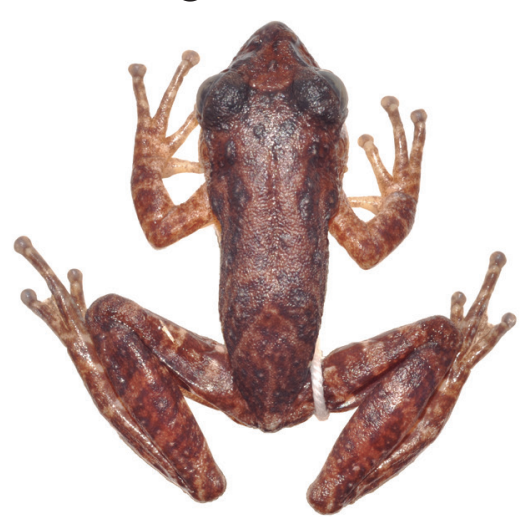

Figure 2. Dorsal view of adult male of (A) Ololygon hiemalis (topotype AAG-UFU 5191, SVL $24.5 \mathrm{~mm}$ ) from Serra das Cabras, Joaquim Egídio, Campinas, São Paulo state, (B) Ololygon ranki (topotype AAG-UFU 399, SVL 27.8 $\mathrm{mm}$ ) from Poços de Caldas, Minas Gerais state, and (C) Ololygon canastrensis (AAG-UFU 4787, SVL 29.7 $\mathrm{mm}$ ) from EPDA-Galheiro, Perdizes, Minas Gerais state, southeastern Brazil. Scale bar = $5 \mathrm{~mm}$. 
Table 2. Morphometric traits ( $\mathrm{mm}$ ) of adult males (topotypes and paratypes) of both Ololygon hiemalis and O. ranki. $N=$ number of analyzed individuals. Values are presented as Mean \pm SD (minimum-maximum).

\begin{tabular}{|c|c|c|c|c|}
\hline \multirow[t]{2}{*}{ Species } & \multicolumn{2}{|c|}{ O. hiemalis } & \multicolumn{2}{|c|}{ O. ranki } \\
\hline & Paratypes $(N=9)$ & Topotypes $(N=8)$ & Paratypes $(N=16)$ & Topotypes $(N=14)$ \\
\hline SVL & $28.0 \pm 1.7(26.0-31.0)$ & $24.3 \pm 0.5(23.3-25.0)$ & $22.0 \pm 2.2(19.8-27.1)$ & $25.3 \pm 2.1(21.3-27.8)$ \\
\hline HW & $10.0 \pm 0.6(9.2-11.3)$ & $9.0 \pm 0.4(8.4-9.5)$ & $8.3 \pm 0.7(7.4-10.2)$ & $9.3 \pm 0.7(8.0-10.2)$ \\
\hline $\mathrm{HL}$ & $8.4 \pm 0.7(7.8-10.0)$ & $7.8 \pm 0.4(7.3-8.2)$ & $7.2 \pm 0.9(6.3-9.5)$ & $8.0 \pm 0.5(7.1-8.8)$ \\
\hline ED & $3.2 \pm 0.2(2.8-3.5)$ & $2.7 \pm 0.1(2.6-3.0)$ & $2.8 \pm 0.3(2.5-3.5)$ & $2.6 \pm 0.3(2.1-3.0)$ \\
\hline IOD & $2.9 \pm 0.3(2.5-3.3)$ & $2.6 \pm 0.2(2.3-3.0)$ & $2.6 \pm 0.3(2.1-3.5)$ & $2.8 \pm 0.2(2.4-3.2)$ \\
\hline IND & $2.0 \pm 0.2(1.7-2.2)$ & $1.6 \pm 0.1(1.5-1.8)$ & $1.7 \pm 0.2(1.4-2.3)$ & $1.7 \pm 0.1(1.5-1.9)$ \\
\hline EN & $2.0 \pm 0.2(1.9-2.3)$ & $2.0 \pm 0.2(1.8-2.3)$ & $1.9 \pm 0.2(1.5-2.4)$ & $2.1 \pm 0.2(1.9-2.5)$ \\
\hline TD & $1.5 \pm 0.1(1.2-1.7)$ & $1.5 \pm 0.1(1.3-1.6)$ & $1.2 \pm 0.2(1.1-1.7)$ & $1.4 \pm 0.2(1.1-1.7)$ \\
\hline SL & $3.2 \pm 0.2(2.9-3.5)$ & $3.3 \pm 0.3(3.0-4.0)$ & $2.9 \pm 0.4(2.2-3.9)$ & $3.3 \pm 0.2(3.0-3.6)$ \\
\hline TL & $14.7 \pm 1.0(13.3-16.2)$ & $13.4 \pm 0.8(12.4-14.4)$ & $11.6 \pm 1.4(10.2-14.8)$ & $13.5 \pm 1.2(11.2-15.4)$ \\
\hline THL & $13.8 \pm 1.1(12.8-16.2)$ & $12.5 \pm 0.7(11.4-13.7)$ & $10.9 \pm 1.1(9.7-13.2)$ & $13.1 \pm 1.2(10.6-14.7)$ \\
\hline $\mathrm{FL}$ & $11.2 \pm 1.0(10.1-12.5)$ & $10.2 \pm 0.6(9.0-11.0)$ & $9.4 \pm 1.1(8.2-12.3)$ & $11.0 \pm 1.1(8.8-12.3)$ \\
\hline $\mathrm{HAL}$ & $7.7 \pm 0.5(7.1-8.7)$ & $6.6 \pm 0.4(6.0-7.1)$ & $6.2 \pm 1.0(5.0-8.5)$ & $7.4 \pm 0.7(6.1-8.2)$ \\
\hline UEW & $2.3 \pm 0.2(2.0-2.7)$ & $2.3 \pm 0.2(2.0-2.5)$ & $2.0 \pm 0.3(1.6-2.6)$ & $2.2 \pm 0.2(1.9-2.6)$ \\
\hline Fin4DW & $1.4 \pm 0.1(1.2-1.6)$ & $1.2 \pm 0.1(1.1-1.3)$ & $1.1 \pm 0.2(0.8-1.5)$ & $1.3 \pm 0.2(1.0-1.5)$ \\
\hline Toe4DW & $1.2 \pm 0.1(1.1-1.3)$ & $1.1 \pm 0.1(0.9-1.2)$ & $0.9 \pm 0.2(0.6-1.3)$ & $1.2 \pm 0.1(1.0-1.4)$ \\
\hline
\end{tabular}

organizations. The main acoustic organization for all three species is herein referred as call Type A (advertisement), each of which (Figures 3 and 4) consist of a series of short squawk-like notes that increase in amplitude and reach their maximum at the end of the call. The call-rise times (i.e. that portion of the call that modulate before the maximum amplitude is achieved) vary however, as noted in the following accounts. In all species, the calls are relatively long. Likewise, each note (short squawk-like) within a call has an ascendant amplitude modulation, reaching the maximum approximately in mid note duration, after which the amplitude decreases. Longest note periods tend to be at the end. The ranges of the number of pulses per note are similar in each of the species; however, the amplitude modulation of the pulses is either complete or incomplete, and the durations and emission rates vary considerably among the three species.

In addition to the call Type $A$, each species emits two other notes-one being a long squawklike note and the other a click-like note; both are emitted sporadically or, in some cases (e.g., male chorus) at higher rates than the Type A call. The association of these notes with one another in 

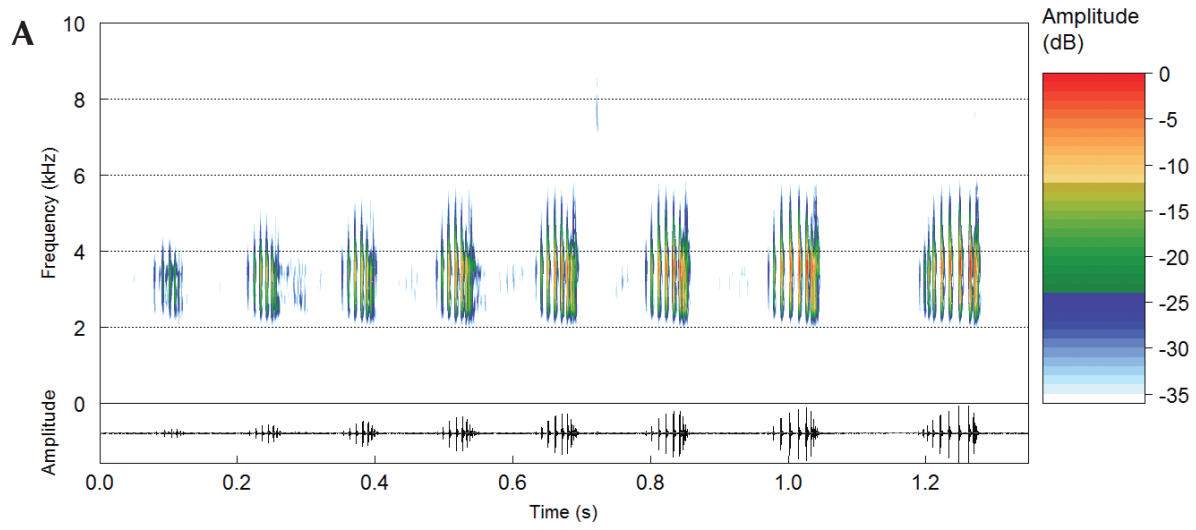

B

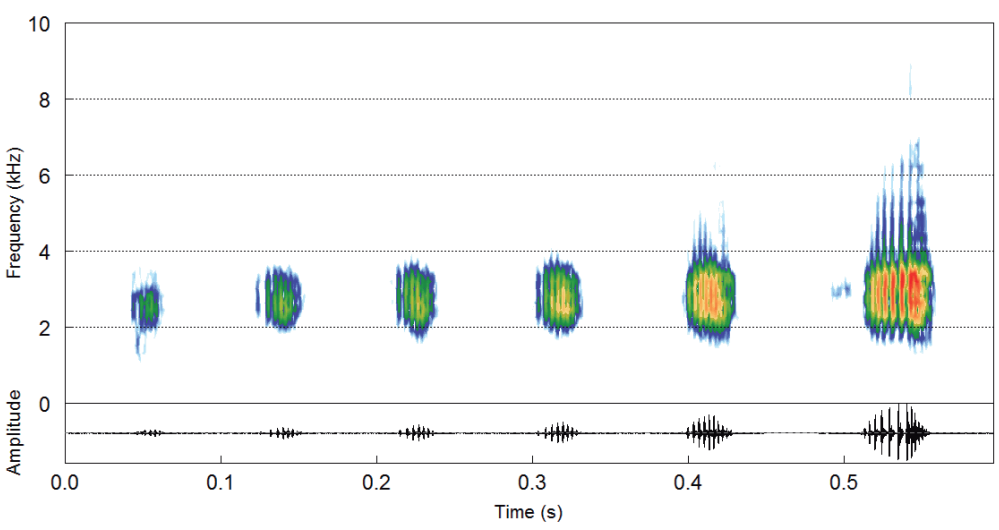

C

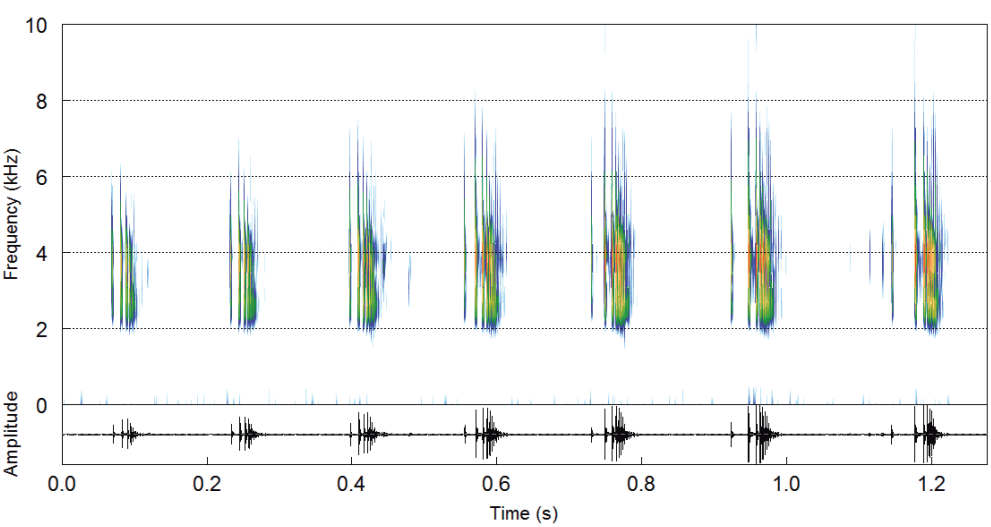

Amplitude

(dB)

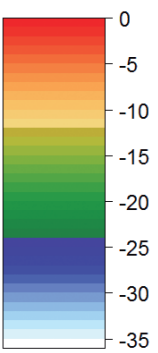

Amplitude

(dB)

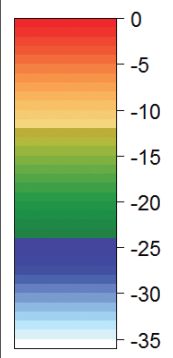

Figure 3. Audiospectrograms and respective oscillograms depicting Type A calls (assumed advertisement calls) of (A) Ololygon hiemalis from Serra das Cabras (Joaquim Egídio, Campinas, São Paulo state), File = Ololygon hiemalCampinasSP12aAAGm671; (B) O. ranki from Poços de Caldas, Minas Gerais state, File = Ololygon hiemalisPocosCaldasMG13aAAGm; (C) O. ranki from Morro do Ferro, Poços de Caldas, Minas Gerais state, File = FNJV_0031425_Ololygon_ranki_Pocos de Caldas_MG_Adao J. Cardoso. See further details on sound files in Appendix II. 

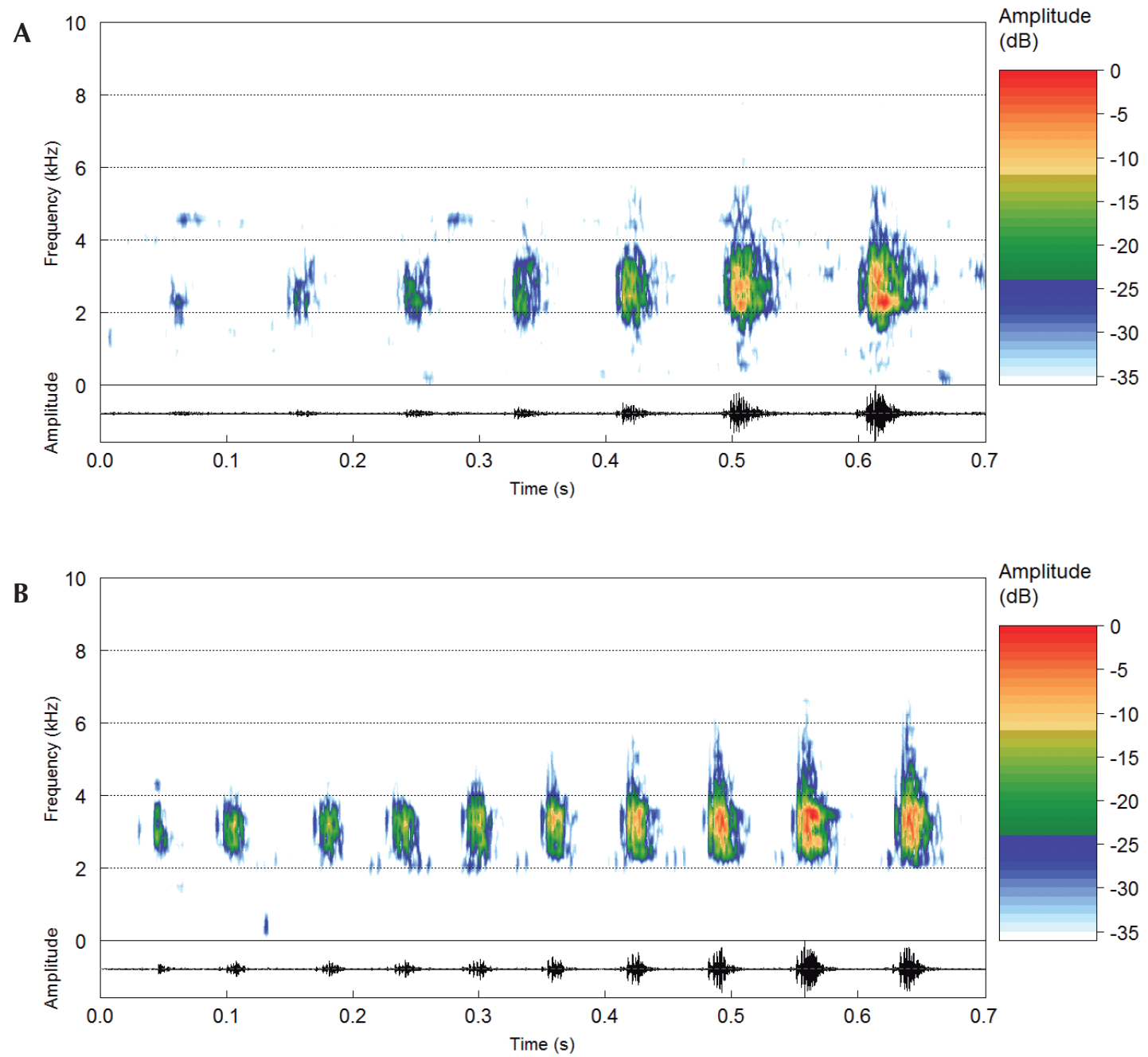

Figure 4. Audiospectrograms and respective oscillograms depicting Type A calls (assumed advertisement calls) of (A) Ololygon canastrensis from Serra da Canastra, São Roque de Minas, Minas Gerais state, File = Ololygon_ canastrCanastraMG1bLBM_AAGmt, and (B) O. canastrensis from EPDA-Galheiro, Perdizes, Minas Gerais state, File = Ololygon_canastrPerdizesMG4bAAGmt. See further details on sound files in Appendix II.

phrases varies as described in the accounts below. The long squawk-like note is a train of pulses, and can have a first part with low amplitude, followed by an increase in amplitude modulation in its last third duration. In O. canastrensis, this note can have portions poorly defined, which results in pulse groupings. The click-like note resembles a short squawklike note, but differs by having a lower pulse rate caused by different pulse organization (last pulses more closely juxtaposed than the others). 
Ololygon hiemalis. - The Type A $(N=13$ males; Figure 3A; Table 3) call-rise time ranges from 70 to $99 \%$. Call duration ranges from 563 to $2434 \mathrm{~ms}($ mean $=1191, \mathrm{SD}=413)$, and are emitted at irregular intervals. Calls have 6-17 short squawk-like notes $($ mean $=9, \mathrm{SD}=2)$ emitted at low rates of 5.7-10.5 notes $/ \mathrm{s}$ (mean = $7.6, \mathrm{SD}=1.2)$. Notes last $21-96 \mathrm{~ms}($ mean $=52$, $\mathrm{SD}=15$ ), and the note-rise time ranges from 41 to $96 \%$ when the amplitude peaks at approximately the half-way point or in the final portion of the note. Initial note period length is 84-172 ms $($ mean $=125, \mathrm{SD}=20)$; mid-call note period length is $89-166 \mathrm{~ms}($ mean $=128, \mathrm{SD}=17)$, and final portion note period length is $105-406 \mathrm{~ms}$ $($ mean $=168, \mathrm{SD}=57)$. Notes have $4-13$ pulses $($ mean $=8, \mathrm{SD}=2)$. Pulse amplitude modulation is complete and duration is $1.0-4.0 \mathrm{~ms}$ (mean = $2.1, \mathrm{SD}=0.5)$. Pulses are emitted at rates of 87.7-222.2 pulses $/ \mathrm{s}$ (mean $=144.8, \mathrm{SD}=28.6$ ). The dominant frequency of the first note ranges from 2077 to $3488 \mathrm{~Hz}($ mean = 2602, SD = 352), whereas that of middle notes ranges from 2411 to $3531 \mathrm{~Hz}($ mean $=2924, \mathrm{SD}=404)$ and that of last notes ranges from 2411 to $3843 \mathrm{~Hz}$ (mean = 3092, SD = 435).

Long squawk-like notes ( $N=4$ males; 19 notes; Figure 1B) vary in length, ranging from 102 to $428 \mathrm{~ms}($ mean $=211, \mathrm{SD}=77)$ and have 13-51 pulses $($ mean $=21, \mathrm{SD}=5)$. Pulses are emitted regularly at rates of 50.0-204.0 pulses/s $($ mean $=107.8, \mathrm{SD}=41.2)$. The dominant frequency of the long squawk-like note ranges from 2625 to $3656 \mathrm{~Hz}$ (mean = 3239, SD = 376). Click-like notes $(N=7$ males; 85 notes; Figure 1C) last from 40 to $117 \mathrm{~ms}$ (mean $=69, \mathrm{SD}=$ 10) and have 4-11 pulses (mean $=6, \mathrm{SD}=1$ ). Pulses are emitted at rates of 40.0-116.3 pulses/s (mean $=76.2, \mathrm{SD}=13.7)$. The dominant frequency of the click-like note ranges from 2296 to $3890 \mathrm{~Hz}$ (mean = 3002, SD = 454). Click-like notes can be emitted as isolated notes (7 instances), except when it is emitted in association with a long squawk-like note (preceding or shortly after in groups of 2-7). In a phrase, a combination of long squawk-like followed by click-like notes, or a long squawklike note alone may precede a call Type A.

Ololygon ranki.-The Type A $(N=6$ males: Figure 3B, C; Table 3) call-rise time ranges from 96 to $99 \%$. Call duration ranges from 491 to $1601 \mathrm{~ms}($ mean $=735, \mathrm{SD}=329)$, and are emitted at irregular intervals. Calls have $6-15$ short squawk-like notes $($ mean $=8, \mathrm{SD}=$ 2) emitted at low rates of 9.0-12.5 notes/s (mean $=10.9, \mathrm{SD}=1.0)$. Notes last $15-51 \mathrm{~ms}($ mean $=$ $30, \mathrm{SD}=10$ ), and the note-rise time ranges from 45 to $80 \%$ when the amplitude peaks at approximately the half-way point or in the final third of the note. Initial note period length is 76-98 ms (mean $=87, \mathrm{SD}=7)$; mid-call note period length is $76-100 \mathrm{~ms}($ mean $=85, \mathrm{SD}=9)$, and final portion note period length is $89-226$ $\mathrm{ms}($ mean $=130, \mathrm{SD}=43)$. Notes have 4-13 pulses $($ mean $=8, \mathrm{SD}=2$ ). Pulse amplitude modulation is complete and duration is 2.0-3.0 $\mathrm{ms}($ mean $=2.3, \mathrm{SD}=0.5)$. Pulses are emitted at rates of 208.3-360.0 pulses $/ \mathrm{s}$ (mean $=274.7, \mathrm{SD}$ = 38.6). The dominant frequency of the first note ranges from 2156 to $3046 \mathrm{~Hz}$ (mean = 2558, SD $=267$ ); whereas that of middle notes ranges from 2109 to $3281 \mathrm{~Hz}($ mean $=2675, \mathrm{SD}=334)$, and that of last notes ranges from 2296 to 3421 $\mathrm{Hz}($ mean $=2882, \mathrm{SD}=327)$.

The long squawk-like note $(N=4$ males; 11 notes; Figure 1E) vary in length, ranging from 62 to $509 \mathrm{~ms}($ mean $=150, \mathrm{SD}=141)$ and have $21-80$ pulses $($ mean $=35, \mathrm{SD}=19)$. Pulses are emitted regularly at rates of 156.1-366.6 pulses/s $($ mean $=271.9, \mathrm{SD}=66.5)$. The dominant frequency of the long squawk-like note ranges from 2484 to $3328 \mathrm{~Hz}($ mean = 3056, SD = 264). Click-like notes ( $N=4$ males; 18 notes; Figure 1F) last from 29 to $49 \mathrm{~ms}$ (mean $=36, \mathrm{SD}=5$ ) and have 5-9 pulses (mean $=6, \mathrm{SD}=1$ ). Pulses are emitted at rates of 111.1-179.5 pulses/s $($ mean $=140.5, \mathrm{SD}=20.8)$. The dominant frequency of the click-like note ranges from 2203 to $3328 \mathrm{~Hz}$ (mean $=2881, \mathrm{SD}=338$ ). Click-like notes can be emitted as isolated notes (2 instances), except when it is emitted in association with a long squawk-like note 
(preceding or shortly after in groups of 3-4). In a phrase, a combination of long squawk-like followed by click-like notes, or a long squawklike note alone may precede a call Type A.

Ololygon canastrensis. - The Type A $(N=3$ males from Serra da Canastra and 4 males from EPDA-Galheiro; Figure 4A, B; Table 3) call-rise time ranges from 74 to $98 \%$. Call duration ranges from 408 to $1825 \mathrm{~ms}($ mean $=564, \mathrm{SD}=315)$, and are emitted at irregular intervals. Calls have 6-27 short squawk-like notes $($ mean $=9, \mathrm{SD}=$ 5) emitted at moderate-to-high rates of 11.1-18.1 notes $/ \mathrm{s}($ mean $=14.9, \mathrm{SD}=1.8)$. Notes last $11-$ $40 \mathrm{~ms}$ (mean $=27, \mathrm{SD}=5$ ), and the note-rise time ranges from 32 to $69 \%$ when the amplitude peaks in the first third to half-way point of the note. Initial note period length is $40-96 \mathrm{~ms}$ (mean $=66, \mathrm{SD}=14)$; mid-call note period length is $54-92 \mathrm{~ms}$ (mean $=65$; $\mathrm{SD}=10)$, and final portion note period length is $66-106 \mathrm{~ms}$ $($ mean $=81, \mathrm{SD}=10)$. Notes have $6-14$ pulses $($ mean $=10, \mathrm{SD}=2)$. Pulse amplitude modulation is incomplete (juxtaposed; except the first one, which is separated from the others) and duration is $1.0-4.0 \mathrm{~ms}$ (mean $=2.1, \mathrm{SD}=0.5$ ). Pulses are emitted at rates of 200.0-625.0 pulses/s (mean = $354.2, \mathrm{SD}=63.6$ ). The dominant frequency of the first note ranges from 2153 to $3234 \mathrm{~Hz}$ (mean $=2525, \mathrm{SD}=399)$; whereas that of middle notes ranges from 2196 to $3531 \mathrm{~Hz}$ (mean $=2751$, SD $=471$ ), and that of last notes ranges from 2250 to $3445 \mathrm{~Hz}$ (mean = 2786, SD = 444). One male released an exceptionally long call lasting 4306 $\mathrm{ms}$, with no remarkably shifts in amplitude throughout the call; this call was preceded by a long squawk-like note.

The long squawk-like note $(N=5$ males; 15 notes; Figure $1 \mathrm{H})$ vary in length, ranging from 230 to $818 \mathrm{~ms}($ mean $=491, \mathrm{SD}=77)$ and have 29-130 pulses $($ mean $=74, \mathrm{SD}=6)$. Pulses are emitted regularly at rates of $100.0-182.1 \mathrm{pulses} / \mathrm{s}$ $($ mean $=149.9, \mathrm{SD}=50.0)$. The dominant frequency of the long squawk-like note ranges from 2325 to $3281 \mathrm{~Hz}($ mean $=2872, \mathrm{SD}=376)$. Click-like notes ( $N=4$ males; 18 notes; Figure 1I) last from 26 to $48 \mathrm{~ms}($ mean $=34, \mathrm{SD}=7)$ and have $6-10$ pulses ( mean $=6, \mathrm{SD}=1)$. Pulses are emitted at rates of $162.8-250.0$ pulses/s $($ mean $=214.4, \mathrm{SD}=30.3)$. The dominant frequency of click-like notes ranges from 2203 to $2906 \mathrm{~Hz}$ (mean = 2581, SD = 182). Click-like notes can be emitted as isolated notes (4 instances), except when it is emitted in association with a long squawk-like note (preceding or shortly after in groups of 2-4). In a phrase, a long squawk-like note alone may precede a call Type A.

\section{Statistical Analyses}

Morphometric features of the topotypes and paratypes of Ololygon hiemalis and O. ranki are summarized in Table 2. Although there is a significant difference in size (Exact WilcoxonMann-Whitney Test, $\mathrm{Z}=2.746, p=0.0053$ ), no single morphometric trait was useful for between-species discrimination; indeed, there is broad overlap of the two species considering the multivariate dataset (Figure 5A).

The multivariate analysis of acoustic data showed a tendency for discrimination between topotypes of $O$. hiemalis and $O$. ranki (Figure $5 \mathrm{~B})$; it is noteworthy that outliers precluded full separation. Temporal traits, such as note duration (Exact Wilcoxon-Mann-Whitney Test, $\mathrm{Z}=-3.37$, $p<0.0001)$ and pulse rate $(\mathrm{Z}=3.37, p=0.0001)$, are the most useful for discrimination between species (Figure 6). The differences in pulse rate reflect the differences found in note duration, as the number of pulses per note overlapped $(\mathrm{Z}=$ $-0.56, p=0.6001)$ between species. Call duration $(\mathrm{Z}=-2.25, p=0.0244)$ is also significantly different.

\section{Discussion}

\section{Remarks on Acoustic Redescriptions}

Haddad and Pombal (1987) described the vocalization of Ololygon hiemalis as being composed of two note types. The first being a frequency-modulated note with 5-8 harmonics, 


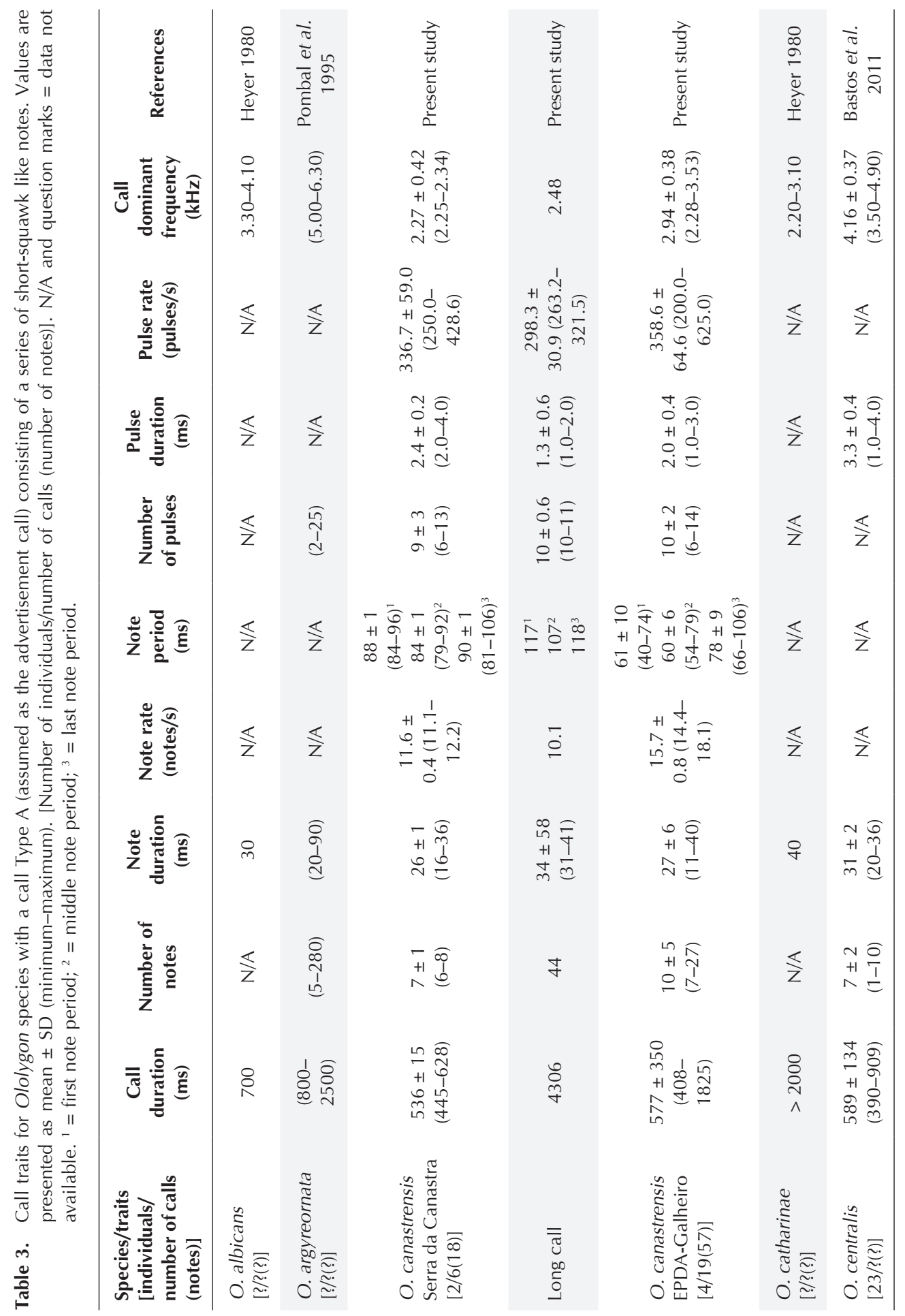




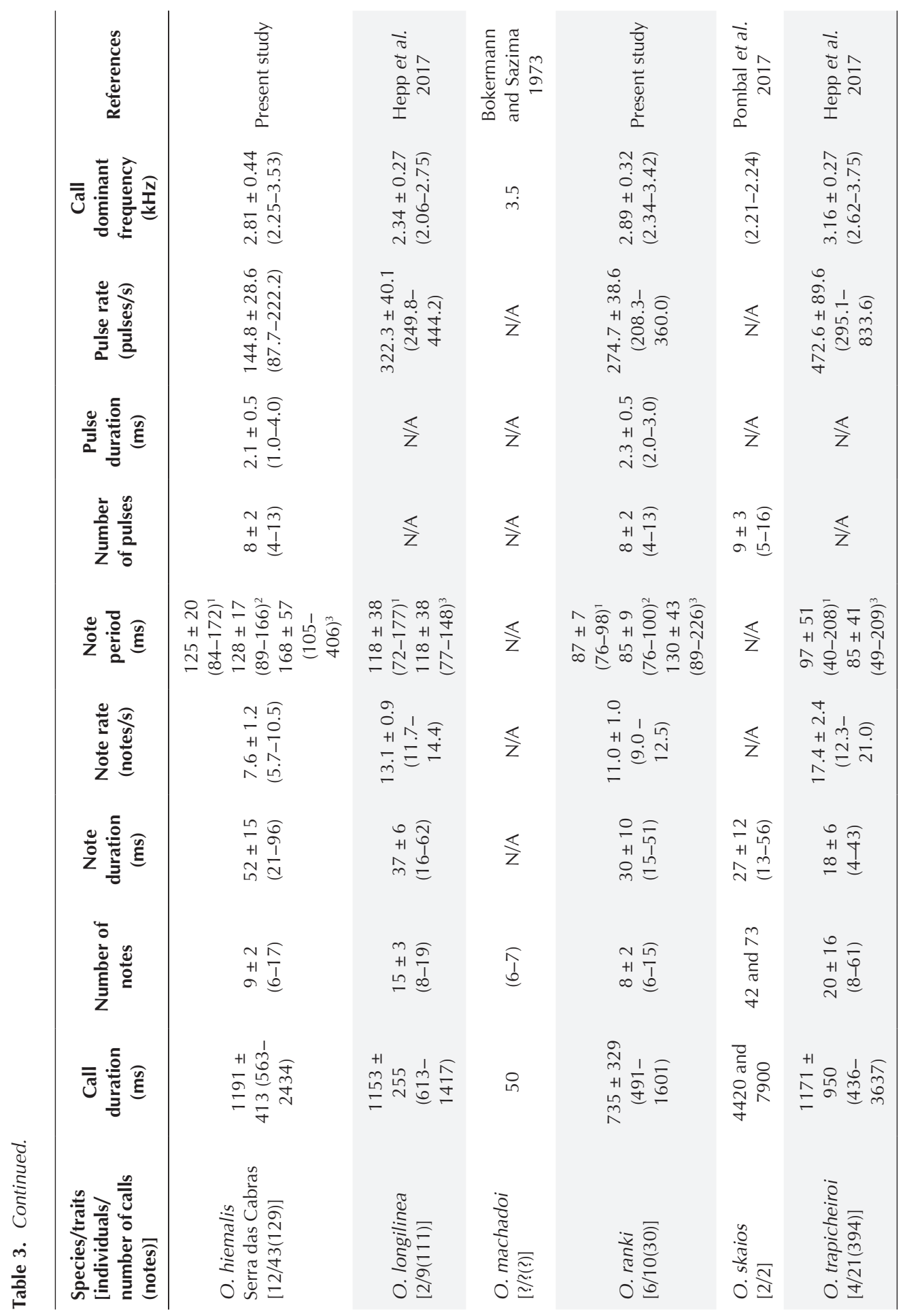


A

- O. hiemalis

- O. ranki

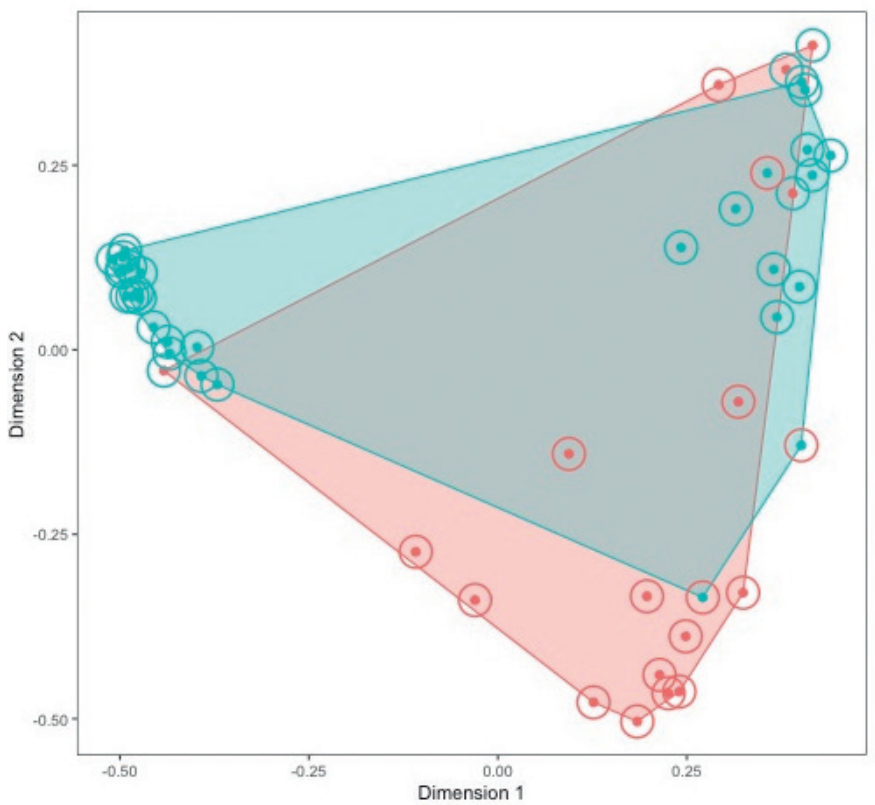

B

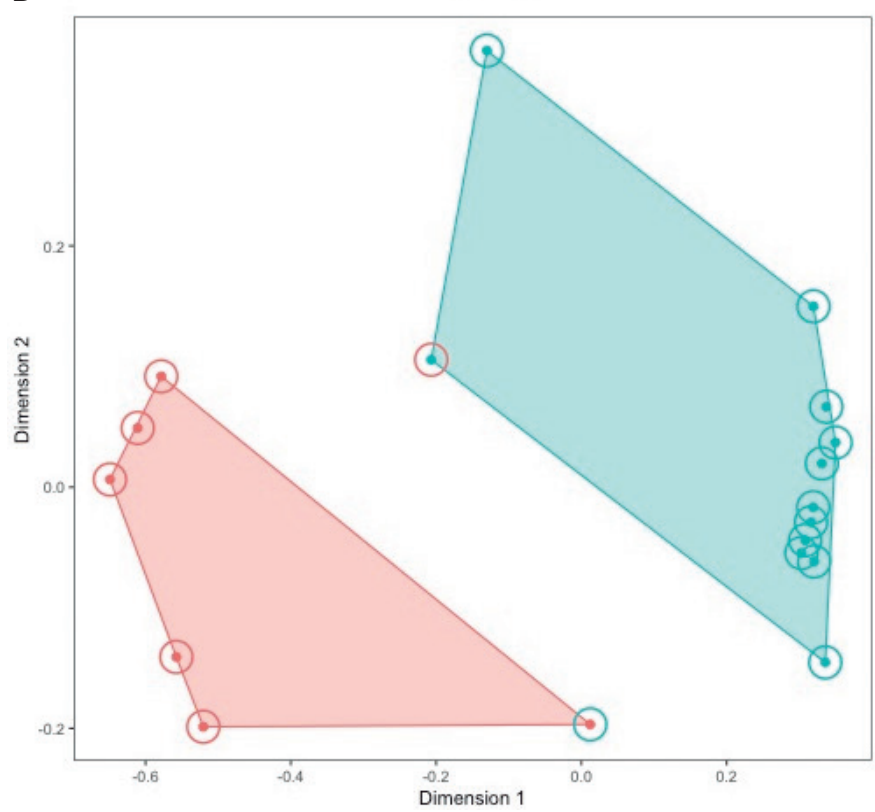

Figure 5. Plots of the two first two axes of a Multidimensional Scale Analysis on the Random Forest result for (A) morphometric data (including the type specimens) of Ololygon hiemalis and O. ranki. Note the broad overlap (low discrimination) between the two species. (B) Acoustic data of topotypical populations of $O$. hiemalis and $O$. ranki, note the partial overlap with outliers representing the misclassifications. 

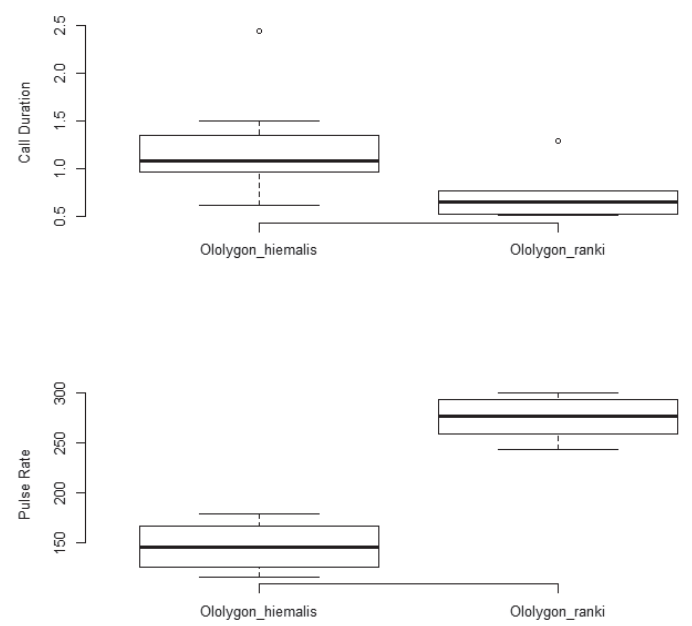
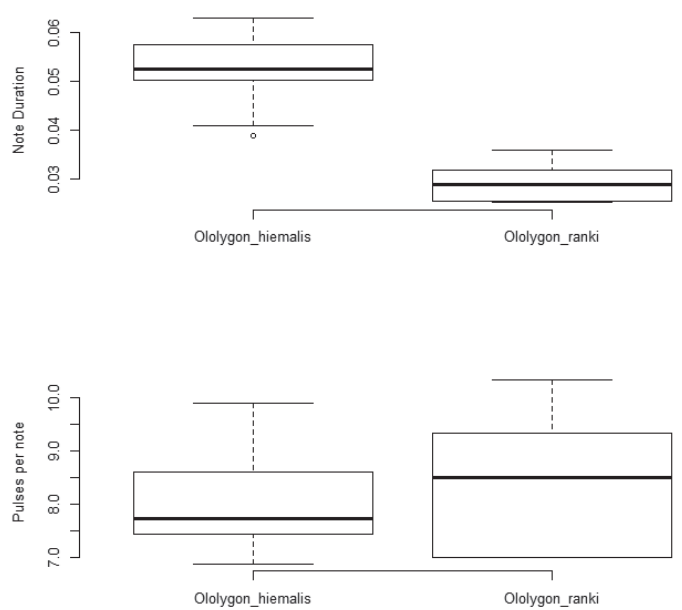

Figure 6. Box and Whiskers Plot of some temporal acoustic traits that were useful for discrimination between topotypical populations of Ololygon hiemalis and O. ranki (except for pulses per note). Differences were considered significant when $p<0.05$.

whose frequency peaked between 2.0 and 3.8 $\mathrm{kHz}$, and a fundamental frequency around $450 \mathrm{~Hz}$. The second type of note corresponds to transitory pulses with emphasized frequency ranging from 2.2 to $4.3 \mathrm{kHz}$. According to their spectrograms, both note types probably correspond to the long squawk- and click-like notes here described, respectively; thus, the call Type A (advertisement) of $O$. hiemalis actually is not described in Haddad and Pombal (1987). In addition, we did not find either harmonic bands or any energy around 450 $\mathrm{Hz}$ in the long squawk-like notes.

In a behavioral paper, Bevier et al. (2008) described some call features (e.g., call rate and duration, calling effort, pulse rate and peak frequency) and figured the call Type A of $O$. hiemalis (as Scinax hiemalis) from Atibaia, São Paulo state. The calls they figured correspond to a series of short squawk-like notes with a noteby-note increase in amplitude modulation, accompanied by a last click-like note. The authors probably considered the click-like note to be part of the call Type A. Indeed, the clicklike note envelope resembles a short squawk-like note (Figure 1A, C), but the former has a different pulse organization and a lower pulse rate. Some call traits described by Bevier et al. (2008) (e.g., duration, pulse rate and dominant frequency) are consistent with our descriptions.

Andrade and Cardoso (1987, 1991) described the vocalization of Ololygon ranki. The quality (low sound input) of the recordings used by them precluded the accurate quantification of any temporal or spectral trait. In general, the pattern we describe for the topotype population conforms to the call Type A (series of short squawk-like notes with increase in amplitude along call duration) and other patterns of emission described by Andrade and Cardoso (1987). However, the short squawk-like notes in their recordings have different grades of pulse juxtaposition than the notes we described, which are organized more regularly (last pulses more juxtaposed; Figure 1D). Moreover, other acoustic organizations, such as different types of association of long squawk-like with click-like notes, were also observed in the original recordings used by Andrade and Cardoso (1987). 
Call traits of Ololygon canastrensis are only known from the original description (probably 1 male recorded; Cardoso and Haddad 1982). The calls are consistent with our descriptions of call Type A (referred there as "nuptial call") and long squawk-like note (referred there as "encounter call"). Our calls from EPDA-Galheiro differ slightly in note rate and consequently in note period, in comparison with those of topotypes (Table 3). These temporal traits are expected to vary according to physical factors (e.g., temperature) and/or male excitement, and because morphologically, the EPDA-Galheiro specimens match the topotypes/type specimens, we consider the acoustic differences found as intraspecific variation. It is also worth mentioning that $O$. canastrensis already had its occurrence reported for EPDA-Galheiro (Oliveira-Filho and Kokubum 2003).

\section{A Reassessment of Acoustic Information for Ololygon hiemalis: Updating Interspecific Comparisons}

Given differences in acoustic data that can be attributed to factors such as recording devices or different analyzed traits, some authors have avoided making interspecific call comparisons within Ololygon (Lourenço et al. 2009, 2013, Pombal et al. 2010). However, a few authors have compared their call descriptions to those of O. hiemalis (e.g., Garey et al. 2012, Pereyra et al. 2012). None of these authors had access to the call Type A (advertisement) of $O$. hiemalis; thus, when making call comparisons, they considered only long squawk-like and click-like notes, instead of the call type A. Given this, we provide an updated interspecific comparison in relation to $O$. hiemalis (Table 3 ).

Call Type A of Ololygon hiemalis resembles those of O. albicans (Bokermann, 1967), O. argyreornata (Miranda-Ribeiro, 1926), O. catharinae (Boulenger, 1888), O. centralis (Pombal and Bastos, 1996), O. longilinea (Lutz, 1968), O. machadoi (Bokermann and Sazima, 1973), O. skaios (Pombal, Carvalho, Canelas and Bastos,
2010), O. rizibilis (Bokermann, 1964), and $O$. trapicheiroi (A. Lutz and B. Lutz, 1954). Each has a series of short squawk-like notes that increase in amplitude modulation note-by-note along call duration. See quantitative comparisons among these species in Table 3 .

The call Type A of Ololygon hiemalis can be differentiated from those of the following congeners: Ololygon agilis (Cruz and Peixoto, 1983) has the call Type A resembling the acoustic pattern of Scinax, being composed of longer notes with lower pulse rates (Nunes et al. 2007, Hepp et al. 2017). Call Type A of $O$. angrensis (Lutz, 1973) is composed of short squawk-like and click-like notes (Garey et al. 2012). Those of $O$. aromothyella (Faivovich, 2005) and $O$. berthae (Barrio, 1962) are characterized by an extensive emission of short squawk-like notes with regular amplitude modulation that are intermingled with long squawk-like notes (Pereyra et al. 2012 and pers. obs.). The call Type A of $O$. heyeri Peixoto and Weygoldt, 1986 is composed of a series of clicklike notes (Hepp et al. 2017), whereas those of $O$. humilis (A. Lutz and B. Lutz, 1954) and $O$. littoralis (Pombal and Gordo, 1991) are composed of short squawk-like notes and clicklike notes (Garey et al. 2012, Hepp et al. 2017). In O. caissara (Lourenço, Zina, Catroli, Kasahara, Favivovich and Haddad, 2016), O. luizotavioi Caramaschi and Kisteumacher, 1989, and $O$. strigilata (Spix, 1824) the call Type A has only a single note (Lourenço et al. 2009, Mendes et al. 2013, Lourenço et al. 2016). The call Type A of $O$. rizibilis differs by having notes with an initial group of more spaced pulses (Bastos and Haddad 2002).

Comparisons between Ololygon hiemalis and O. ranki

In the original description of Ololygon hiemalis, Haddad and Pombal (1987) distinguished it from $O$. ranki by differences in SVL, the presence of an inguinal folding in $O$. hiemalis, along with differences in coloration patterns and 
vocalization. However, we could not clearly differentiate both species based on our data from the topotypes and our reevaluation of the type series of the two taxa. Both have an inguinal folding and the dorsal color patterns are indistinguishable (Figure 2A, B). The ranges in snout-vent length of the two species overlap between species, although $O$. ranki has a significant smaller SVL. In addition, the tadpoles of $O$. hiemalis and $O$. ranki seem to resemble one another (Andrade and Cardoso 1987, Haddad and Pombal 1987). In the description of $O$. hiemalis, Haddad and Pombal (1987) considered only the long squawk- and click-like notes when they compared the vocalization of $O$. hiemalis in relation to that of $O$. ranki. In our reassessment of the vocalizations of the two species, we noted that their Type A calls also have similar acoustic structures (Figure 3). However, there are quantitative and significant differences in the durations of calls and notes and in pulse rates, and considerable overlaps in the remaining traits (Figure 6).

Because we did not find major differences in morphology or structural (qualitative) features of vocalization, we then consider Ololygon hiemalis and $O$. ranki to be phenotypically indistinguishable. With regard to the differences in quantitative traits of the call Type $\mathrm{A}$, it is important to note that we could not account for environmental variables that might influence the observed values because we lacked complete data about temperature, humidity, and others. The effect of temperature on call and note durations is well documented (Gerhardt 1994), but the pulse rate is a static acoustic property that potentially is useful in species recognition (Wells 2007). The differences in pulse rates in short squawk-like notes between $O$. hiemalis and $O$. ranki are reflected by the note durations, because both species emit approximately the same number of pulses per note (Figure 6). This trait also might be related to physiological and/or behavioral responses (Cocroft and Ryan 1995), and this seems likely because in a distinct social context, both species broadcast a similar single note (click-like), which has lower pulse rate and different pulse organization than a short squawklike note. This suggests that the differences in pulse rate may reflect behavioral responses, instead of anatomical (i.e., muscular) limitations (Martin 1972) that might be involved in a reproductive isolating mechanism between both species (Bosch and De la Riva 2004, Wells 2007). Given the absence of data on the effect of environmental variables on these acoustic traits, it is clear that a more integrative approach (e.g., genetics, biogeography and ecology) is necessary to address the taxonomic status of $O$. hiemalis in relation to $O$. ranki.

The taxonomic delimitation of both species is important because Ololygon ranki appears as "vulnerable" in lists of threatened species of the Minas Gerais state (Biodiversitas 2007, Copam 2010). Both $O$. hiemalis and $O$. ranki were described in 1987, although the description of $O$. hiemalis was published one day before to that of O. ranki (A. C. C. Lourenço pers. comm.). If future works addressing other data bases would consider $O$. ranki as a junior synonym with respect to $O$. hiemalis, then $O$. ranki should be taken out of the Minas Gerais red list given the broad geographical range of $O$. hiemalis which includes Minas Gerais, Sao Paulo and Rio de Janeiro states (see the Appendix of Lourenço et al. 2016), not being under any degree of threat of extinction.

\section{Final Remarks}

Many species of Ololygon have complex vocalizations that are associated with different behaviors (Bastos and Haddad 2002, Bastos et al. 2011). As in the three species considered here, their vocal repertoires consist of at least two types of signals, which can be emitted in complex organizations (Pereyra et al. 2012, Hepp et al. 2017). All signal types reported here are similar to those described for other species of the genus (Bastos and Haddad 2002, Bastos et al. 2011, Hepp et al. 2017), especially the call Type A, which is used in interspecific 
comparisons and thus, assumed to operate as an advertisement call. The long squawk-like and click-like notes in the three species studied here most likely convey aggressive messages; these can be broadcast alone, associated with one another, or both associated with a call Type A. These patterns may have dual function in vocalization; thus males can emit aggressive signals to other males and mating signals to females in a single calling effort (Narins and Capranica 1978, Larson 2004, Pereyra et al. 2012).

Despite the complexity of the acoustic emissions within Ololygon, many species of the genus share a stereotyped Type A call pattern (i.e., a series of notes with increase in amplitude along call duration; Pombal et al. 2010, Bastos et al. 2011, Hepp et al. 2017). This may be a phylogenetically conserved trait (Cocroft and Ryan 1995, Erdtmann and Amézquita 2009), which seems to reflect similarities in the processes of sound production (Martin 1972). As Hepp et al. (2017) stated, the phylogenetic application of acoustic traits would inform the evolutionary history of this stereotyped pattern, as well as other acoustic organizations in Ololygon.

Comparisons of advertisement signals sometimes are the determinant factor for taxonomic delimitations (Padial et al. 2008, Carvalho and Giaretta 2013, Köhler et al. 2017). Therefore, we emphasize the need and importance of detailed and comprehensive call characterizations, along with redescriptions of outdated accounts, aiming to support future studies involving acoustic comparisons among species of Ololygon and other closely related clades. Moreover, the taxa included in the present work may be targeted for behavioral studies (Bastos and Haddad 2002, Bastos et al. 2011) to clearly establish the functions of the acoustic repertoire observed in Ololygon species, and this is especially needed because the call Type A (advertisement call) of these species may vary in composition, presenting complex combinations of short squawklike with long squawk-like notes (e.g., $O$. angrensis, O. humilis, O. littoralis), or even being composed of a series of click-like notes (e.g., O. heyeri) (Hepp et al. 2017).

\section{Acknowledgments}

We thank Felipe S. Andrade, Lucas B. Martins, Isabelle A. Haga, and Thiago R. Carvalho for making available call recordings. Jaime Bertoluci and Linda Trueb made valuable comments and reviewed the English of this manuscript. Fonoteca Neotropical Jacques Vielliard for providing recordings of $O$. ranki. Célio F. B. Haddad and Luis Felipe Toledo allowed the examination of specimens under their care. Financial support granted by $\mathrm{CNPq}$ and FAPEMIG to AAG team. A grant was provided by $\mathrm{CNPq}$ to AAG. A Masters fellowship by CNPq was provided to DLB (process \#159817/20153 ). Collection permits were conceded by ICMBio/ SISBIO (\#24954-2; \#02015.008064/02-51).

\section{References}

Andrade, G. V. and A. J. Cardoso. 1987. Reconhecimento do grupo rizibilis: descrição de uma nova espécie de Hyla (Amphibia, Anura). Revista Brasileira de Zoologia 3: $433-440$.

Andrade, G. V. and A. J. Cardoso. 1991 Descrição. de larvas e biologia de quatro espécies de Hyla (Amphibia, Anura). Revista Brasileira de Biologia 51: 391-402.

Archer, E. 2014. rfPermute: Estimate Permutation p-values for Random Forest Importance Metrics. Version 1.6.1. [package on R software]. URL: http://CRAN.R-project. org/package $=$ rfPermute.

Bastos, R. P. and C. F. B. Haddad. 2002. Acoustic and aggressive interactions in Scinax rizibilis (Anura: Hylidae) during the reproductive activity in southeastern Brazil. Amphibia-Reptilia 23: 97-104.

Bastos, R. P., M. B. Alcantara, A. R. Morais, R. Lingnau, and L. Signorelli. 2011. Vocal behaviour and conspecific call response in Scinax centralis. Herpetological Journal 21: $43-50$.

Bevier, C. R., F. R. Gomes, and C. A. Navas. 2008. Variation in call structure and calling behavior in treefrogs of the genus Scinax. South American Journal of Herpetology 3: 196-206. 
Bioacoustics Research Program. 2014. Raven Pro: Interactive Sound Analysis Software. Version 1.5. URL: http:// www.birds.cornell.edu/raven.

Biodiversitas. 2007. Revisão das Listas das Espécies da Flora e da Fauna Ameaçadas de Extinção do Estado de Minas Gerais: Relatório Final, Volume 3. Belo Horizonte. Fundação Biodiversitas. 142 pp.

Bokermann, W. C. A. and I. Sazima. 1973. Anfíbios da Serra do Cipó, Minas Gerais, Brasil. 1: duas espécies novas de Hyla (Anura, Hylidae). Revista Brasileira de Biologia 33: 521-528.

Bosch, J. and I. De la Riva. 2004. Are frog calls modulated by the environment? An analysis with anuran species from Bolivia. Canadian Journal of Zoology 82: 880 888.

Brunetti, A. E., C. Taboada, and J. Faivovich. 2015. Extended vocal repertoire in Hypsiboas punctatus (Anura: Hylidae). Journal of Herpetology 49: 46-52.

Cardoso, A. J. and C. F. B. Haddad. 1982. Nova espécie de Hyla da Serra da Canastra (Amphibia, Anura, Hylidae). Revista Brasileira de Biologia 42: 499-503.

Carvalho, T. R. and A. A. Giaretta. 2013. Taxonomic circumscription of Adenomera martinezi (Bokermann, 1956) (Anura: Leptodactylidae: Leptodactylinae) with the recognition of a new cryptic taxon through a biacoustic approach. Zootaxa 3701: 207-237.

Carvalho, T. R., L. B. Martins, B. F. V. Teixeira, L. B. Godinho, and A. A. Giaretta. 2015. Intraspecific variation in acoustic traits and body size, and new distributional records for Pseudopaludicola giarettai Carvalho, 2012 (Anura,Leptodactylidae,Leiuperinae): implications for its congeneric diagnosis. Papéis Avulsos de Zoologia 55: $245-254$.

Cocroft, R. B. and M. J. Ryan. 1995. Patterns of advertisement call evolution in toads and chorus frogs. Animal Behaviour 49: 283-303.

Copam. 2010. Deliberação Normativa COPAM n 147, de 30 de abril de 2010: aprova a lista de espécies ameaçadas de extinção da fauna do estado de Minas Gerais. Diário do Executivo, Minas Gerais. Brasil.

Duellman, W. E., A. B. Marion, and S. B. Hedges. 2016. Phylogenetics, classification, and biogeography of the treefrogs (Amphibia: Anura: Arboranae). Zootaxa 4104: $1-109$.

Erdtmann, L. and A. Amézquita. 2009. Differential evolution of advertisement call traits in Dart-Poison Frogs (Anura: Dendrobatidae). Ethology 115: 801-811.

Faivovich, J. 2002. A cladistic analysis of Scinax (Anura: Hylidae). Cladistics 18: 367-393.
Faivovich, J., C. F. B. Haddad, P. C. A. Garcia, D. Frost, J. A. Campbell, and W. C. Wheeler. 2005. Systematic review of the frog family Hylidae, with special reference to Hylinae: phylogenetic analysis and taxonomic revision. Bulletin of the American Museum of Natural Hististory 294: 1-240.

Faria, D. C. C., L. Signorelli, A. R. Morais, R. P. Bastos, and N. M. Maciel. 2013. Geographic structure and acoustic variation in populations of Scinax squalirostris (A. Lutz, 1925) (Anura: Hylidae). North-Western Journal of Zoology 9: 329-336.

Forti, L. R., R. Lingnau, L. C. Encarnação, J. Bertoluci, and L. F. Toledo. 2017. Can treefrog phylogeographical clades and species' phylogenetic topologies be recovered by bioacoustical analyses? PLOS ONE 12: e0169911.

Garey, M. V., T. R. N. Costa, A. M. X. Lima, L. F. Toledo, and M. T. Hartmann. 2012. Advertisement call of Scinax littoralis and S. angrensis (Amphibia: Anura: Hylidae), with notes on the reproductive activity of $S$. littoralis. Acta Herpetologica 7: 297-308.

Gerhardt, H. C. 1994. The evolution of vocalization in frogs and toads. Annual Reviews of Ecology and Systematics 25: 293-324.

Haddad, C. F. B. and J. P. Pombal Jr. 1987. Hyla hiemalis, nova espécie do grupo rizibilis do Estado de São Paulo (Amphibia, Anura, Hylidae). Revista Brasileira de Biologia 47: 127-132.

Hepp, F., A. C. C. Lourenço, and J. P. Pombal Jr. 2017. Bioacoustics of four Scinax species and a review of acoustic traits in the Scinax catharinae species group (Amphibia: Anura: Hylidae). Salamandra 53: 212-230.

Heyer, W. R. 1980. The calls and taxonomic positions of Hyla giesleri and Ololygon opalina (Amphibia: Anura: Hylidae). Proceedings of the Biological Society of Washington 93: 655-661.

Hothorn, T., K. Hornik, M. A. van de Wiel, and A. Zeileis. 2008. Implementing a class of permutation tests: the coin package. Journal of Statistical Software 28: 1-23.

Jombart, T. 2008. Adegenet: a R package for the multivariate analysis of genetic markers. Bioinformatics 24: 1403 1405.

Jombart, T., S. Devillard, and F. Balloux. 2010. Discriminant analysis of principal components: a new method for the analysis of genetically structured populations. BMC Genetics 11: 94-109.

Köhler, J., M. Jansen, A. Rodríguez, P. J. R. Kok, L. F. Toledo, M. Emmrich, F. Glaw, C. F. B. Haddad, M-O. Rödel, and M. Vences. 2017. The use of bioacoustics in anuran taxonomy: theory, terminology, methods and 
recommendations for best practice. Zootaxa 4251: $1-124$

Larson, K. A. 2004. Advertisement call complexity in northern leopard frogs, Rana pipiens. Copeia 2004: 676-682.

Liaw, A. and M. Wiener. 2002. Classification and regression by randomForest. $R$ News 2: 18-22.

Lourenço, A. C. C., D. Baêta, V. S. Monteiro, and M. R. S. Pires. 2009. O canto de anúncio de Scinax luizotavioi (Caramaschi \& Kisteumacher, 1989) (Anura, Hylidae). Arquivos do Museu Nacional 67: 73-79.

Lourenço, A. C. C., A. L. G. Carvalho, D. Baêta, T. L. Pezzuti, and F. S. F. Leite. 2013. A new species of the Scinax catharinae group (Anura, Hylidae) from Serra da Canastra, southwestern state of Minas Gerais, Brazil. Zootaxa 3613: 573-588.

Lourenço, A. C. C., J. Zina, G. F. Catroli, S. Kasahara, J. Faivovich, and C. F. B. Haddad. 2016. A new species of the Scinax catharinae group (Anura: Hylidae) from southeastern Brazil. Zootaxa 4154: 415-435.

Martin, W. F. 1972. Evolution of vocalization in the genus Bufo. Pp. 279-309 in W. F. Blair (ed.), Evolution in the Genus Bufo. Austin. University of Texas Press.

Mendes, C. V. M., E. Marciano Junior, D. S. Ruas, R. M. Oliveira, and M. Solé. 2013. Advertisement call of Scinax strigilatus (Spix, 1824) (Anura: Hylidae) from southern Bahia, Brazil. Zootaxa 3647: 499-500.

Narins, P. M. and R. R. Capranica. 1978. Communicative significance of the two-note call of the treefrog Eleutherodactylus coqui. Journal of Comparitive Physiology 127: 1-9.

Nunes, I., R. S. Santiago, and F. A. Juncá. 2007. Advertisement calls of four hylid frogs from the state of Bahia, Northeastern Brazil (Amphibia, Anura, Hylidae). South American Journal of Herpetology 2: 89-96.

Oliveira-Filho, J. C. and M. N. C. Kokubum. 2003. Geographic distribution: Scinax canastrensis. Herpetological Review 34: 163.

Padial, J. M., J. Köhler, A. Muñoz, and I. De la Riva. 2008. Assessing the taxonomic status of tropical frogs through bioacoustics: geographical variation in the advertisement calls in the Eleutherodactylus discoidalis species group (Anura). Zoological Journal of the Linnean Society 152: 353-365.

Pereyra, M. O., C. Borteiro, D. Baldo, F. Kolenc, and C. E. Conte. 2012. Advertisement call of the closely related species Scinax aromothyella Faivovich, 2005 and S. berthae (Barrio, 1962), with comments on the complex calls in the S. catharinae group. Herpetological Journal 22: $133-137$.

Pombal, J. P., Jr. and R. P. Bastos. 1996. Nova espécie de Scinax Wagler, 1830 do Brasil Central (Amphibia, Anura, Hylidae). Boletim do Museu Nacional, Nova Série, Zoologia 371: 1-11.

Pombal, J. P., Jr., R. P. Bastos, and C. F. B. Haddad. 1995. Vocalizações de algumas espécies do gênero Scinax (Anura, Hylidae) do sudeste do Brasil e comentários taxonômicos. Naturalia 20: 213-225.

Pombal, J. P., Jr., R. R. Carvalho Jr., M. A. S. Canelas, and R. P. Bastos. 2010. A new Scinax of the S. catharinae species group from Central Brazil (Amphibia: Anura: Hylidae). Zoologia 27: 795-802.

R Development Core Team. 2015. R: a language and environment for statistical computing. Version 3.2.3. URL: http://www.R-project.org.

Sueur, J., T. Aubin, and C. Simonis. 2008. Seewave: a free modular tool for sound analysis and synthesis. Bioacoustics 18: 213-226.

Toledo, L. F., I. A. Martins, D. P. Bruschi, M. A. Passos, C. Alexandre, and C. F. B. Haddad. 2015. The anuran calling repertoire in the light of social context. Acta Ethologica 18: 87-99.

Watters, J. L., S. T. Cummings, R. L. Flanagan, and C. D. Siler. 2016. Review of morphometric measurements used in anuran species descriptions and recommendations for a standardized approach. Zootaxa 4072: 477-495.

Wells, K. D. (ed.). 2007. The Ecology and Behavior of Amphibians. Chicago. The University of Chicago Press. 1148 pp.

Editor: Jaime Bertoluci 
Appendix I. Specimens examined.

Ololygon canastrensis: BRAZIL, MINAS GeRAIS: Altinópolis (ZUEC 3822); Araxá (CFBH 11580, 11581); Furnas (CFBH 17346, 17347, 17354, 17358, 17359); Perdizes, EPDA-Galheiro (AAG-UFU 371-372, 4784-4787, 4987); São Roque de Minas, Parque Nacional da Serra da Canastra (CFBH 29, 9154, 6254 paratype, ZUEC 4188, 4189, 4191, 4193 paratypes, 4357, 4442-4444, 4460, 10851); Vargem Bonita (ZUEC 4336-4340). SÃo PAULO: Pedregulho (CFBH 13975-13977, 13438, 13439).

Ololygon hiemalis: BRAZIL, São PAUlo: Joaquim Egídio, Campinas (AAG-UFU 5190-5192, 4432-4436, CFBH 189, 190, 192, 6262-6263 paratypes, ZUEC 5860-5864 paratypes, 5856, 5859, 6847-6851, 5974).

Ololygon ranki: BRAZIL, MINAS GeraIS: Poços de Caldas (AAG-UFU 392-402, 972, 5517, 5518, CFBH 6256, 6259 paratypes, 35561, 92, 3908, CFBH 35901-35907, 53912, 35892-35899, ZUEC 4490, 4309, 4535, 5027-5032, 54005401, 5403-5404, 5406 paratypes). 
Bang and Giaretta

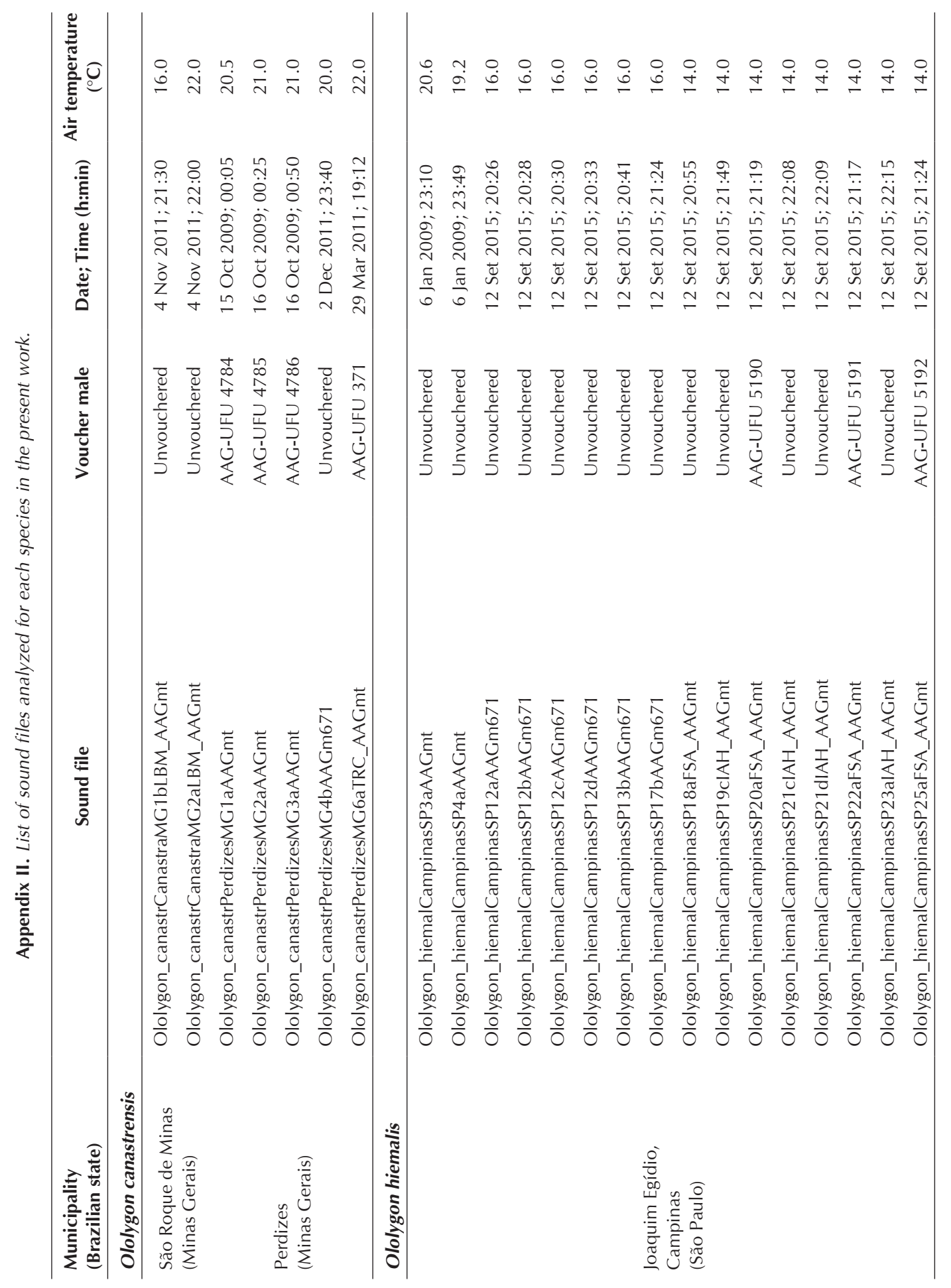


A reassessment of the vocalizations of three species of Ololygon from Brazil

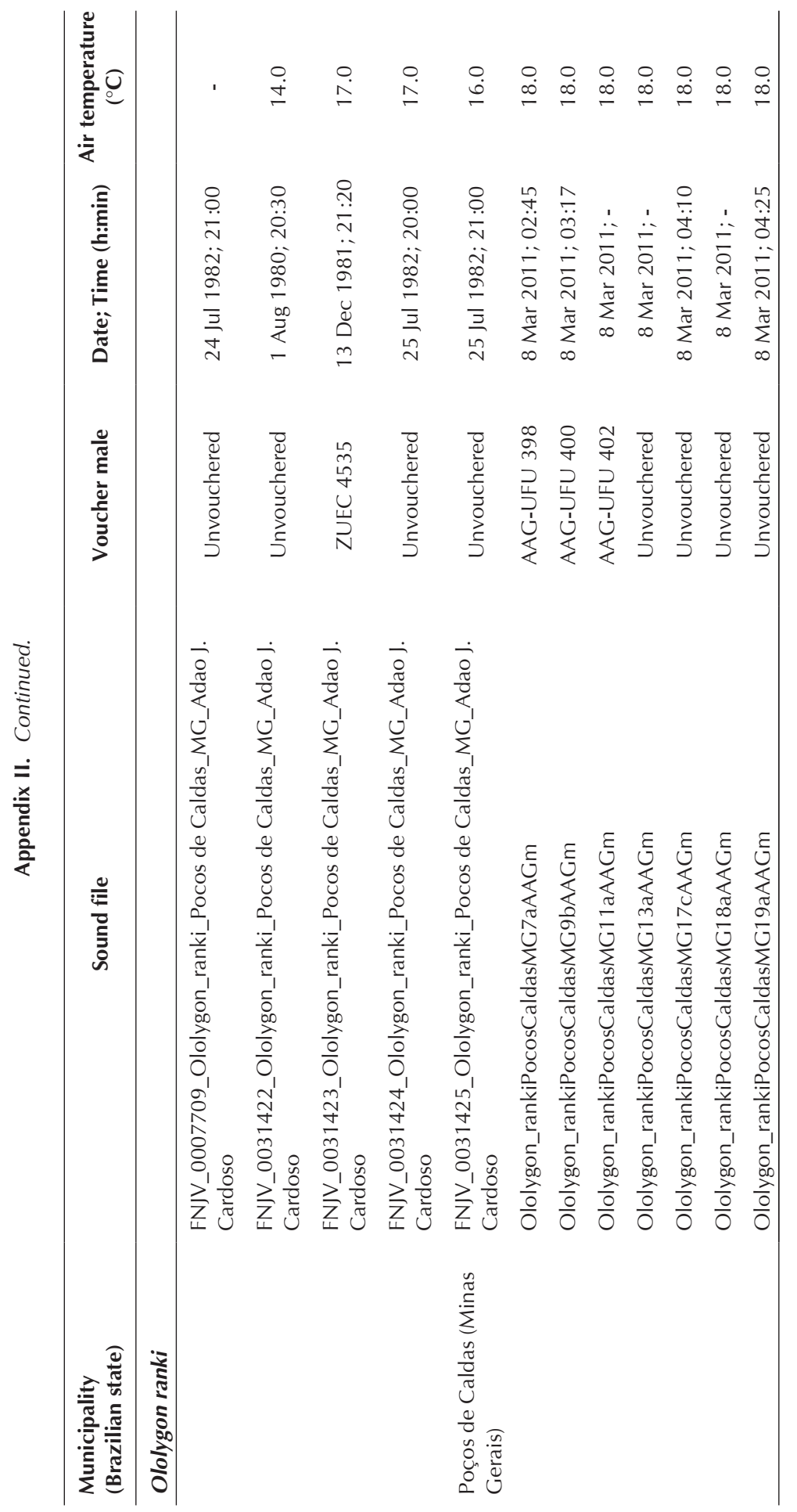

Phyllomedusa - 16(1), June 2017 